\title{
Retraction Note: Urachal tumour: case report of a poorly understood carcinoma
}

Stefano Scabini ${ }^{1 *}$, Edoardo Rimini ${ }^{1}$, Emanuele Romairone ${ }^{1}$, Renato Scordamaglia', Luigi Vallarino²,

Veronica Giasotto ${ }^{3}$, Carlo Ferro ${ }^{3}$ and Valter Ferrando ${ }^{1}$

Retraction Note: World J Surg Onc 7, 82 (2009)

https://doi.org/10.1186/1477-7819-7-82

The Editor-in-Chief has retracted this article because of overlap with an article by Fujiyama et al [1].

The authors have not responded to any correspondence regarding this retraction.

\section{Author details}

'Department of Emato-Oncology, AOU San Martino Hospital, Genoa, Italy.

${ }^{2}$ ASL 3, Genoa, Italy. ${ }^{3}$ Department of Radiology, AOU San Martino Hospital, Genoa, Italy.

Published online: 29 June 2021

\section{References}

1. Fujiyama C, Nakashima N, Tokuda Y, et al. Int J Urol. 2007;14:966-8. https:// doi.org/10.1111/j.1442-2042.2007.01857.x.

The original article can be found online at https://doi.org/10.1186/1477-7819$7-82$.

* Correspondence: stefanoscabini@libero.it

1Department of Emato-Oncology, AOU San Martino Hospital, Genoa, Italy

Full list of author information is available at the end of the article

(c) The Author(s). 2021 Open Access This article is licensed under a Creative Commons Attribution 4.0 International License, which permits use, sharing, adaptation, distribution and reproduction in any medium or format, as long as you give appropriate credit to the original author(s) and the source, provide a link to the Creative Commons licence, and indicate if changes were made. The images or other third party material in this article are included in the article's Creative Commons licence, unless indicated otherwise in a credit line to the material. If material is not included in the article's Creative Commons licence and your intended use is not permitted by statutory regulation or exceeds the permitted use, you will need to obtain permission directly from the copyright holder. To view a copy of this licence, visit http://creativecommons.org/licenses/by/4.0/. The Creative Commons Public Domain Dedication waiver (http://creativecommons.org/publicdomain/zero/1.0/) applies to the data made available in this article, unless otherwise stated in a credit line to the data. 